\title{
Leader Humor and Knowledge Sharing Behavior: The Role of Leader-Member Exchange
}

\author{
Muhammad Rasyid Abdillah \\ Department of Management, Universitas Lancang Kuning, Pekanbaru, Indonesia \\ Email address: \\ m.rasyidabdillah@unilak.ac.id
}

\begin{abstract}
A function in using humor in the workplace is to build relationships between employees involved in such behavior. This study seeks to explain the relationship between leader humor and knowledge-sharing behavior using social exchange theory. Specifically, this study endeavors to explain the mechanism process underlying the relationship between leader humor and knowledge-sharing behavior through the leader-member exchange. To test the hypotheses, the current study collected data from employees working at communication and information company in Pekanbaru City, Riau, Indonesia with utilizing PLS-SEM analysis. The finding shows that leader humor can encourage employee knowledge sharing behavior through the relationship quality between leaders and employees.
\end{abstract}

Keywords: leader humor, leader-member exchange, knowledge-sharing behavior.

\begin{abstract}
Abstrak: Salah satu fungsi dalam penggunaan humor di tempat kerja adalah untuk membangun hubungan antara karyawan yang terlibat dalam perilaku tersebut. Penelitian ini berupaya menjelaskan dampak dari perilaku humor pemimpin terhadap perilaku berbagi pengetahuan karyawan dengan menggunakan perspektif social exchange theory. Secara khusus, studi ini berupaya menjelaskan pengaruh dari perilaku humor pemimpin terhadap perilaku berbagi pengetahuan karyawan melalui mekanisme leader-member exchange. Untuk membuktikan hipotesis yang diajukan, peneltian ini mengumpulkan data dari karyawan yang bekerja pada sebuah perusahaan yang bergerak pada industri komunikasi dan informasi yang berlokasi di Kota Pekanbaru, Provinsi Riau. Selanjutnya, penelitian ini akan menggunakan analisis SEM-PLS dalam menguji hipotesis-hipotesis yang diajukan dalam studi ini. Penelitian ini menemukan bahwa perilaku humor pemimpin dapat mendorong perilaku berbagi pengetahuan karyawan melalui kualitas hubungan antara pemimpin dan karyawan.
\end{abstract}

Kata Kunci: humor pemimpin, leader-member exchange, perilaku berbagi pengetahuan.

\section{INTRODUCTION}

The use of humor for leaders can be an interpersonal resource that encourages highquality interaction between leaders and employees (Cooper et al., 2018). Humor is a valuable strength of character possessed by leaders (Cooper and Sosik, 2012). It shows that 
leaders have the ability in social communication intended to amuse their subordinates (Cooper, 2005). Humor behavior carried out by leaders towards their subordinates shows that they are trying to reduce the social distance between them and their subordinates. Leader humor is considered by subordinates as a form of friendliness from leaders to their subordinates. Hence, such behavior can improve high-quality interactions between subordinates and their leaders (Kong et al., 2019).

Positive outcomes expected by organizations with high-quality interactions between leaders and subordinates are subordinates' extraordinary behaviors, such as knowledge sharing (Kim et al., 2017). Knowledge sharing (KS) behavior is considered as productive knowledge behavior which is a key component in knowledge management systems (Curado et al., 2017; Ismail et al., 2015; Rosendaal and Bijlsma-Frankema, 2015; Sudhindra et al., 2019; Vlachos et al., 2020; Wipawayangkool and Teng, 2019; Yen et al., 2015; Yeo and Marquardt, 2015). How to encourage subordinates to share their knowledge they have is an essential responsibility for organizations because in order to manage knowledge effectively in organizations, knowledge ownership embedded in a subordinate is seen as a barrier (Barley et al., 2018). Organizations cannot force their employees to share their ideas or experiences with other organization members because they do not have employee intellectual assets (Connelly et al., 2012;2019). Hence, an investigation of factors encouraging subordinates to share their knowledge is very essential for academics and practitioners.

Prior studies have tried to investigate what causes subordinates to share their knowledge, including motivational, environmental, and individual factors (e.g., Carmeli et al., 2013; Kakar, 2018; Li et al., 2015; Pangil and Chan, 2014). However, only little attention is given by scholars to investigate the link between leadership styles or leader behaviors and subordinates' KS behavior (Bavik et al., 2018).

Managers and scholars in leadership and management studies have recognized that leadership behaviors or styles have a very essential role in shaping subordinates' certain behaviors in organizations (Inceoglu et al., 2018). Initial evidence has revealed that ethical leadership could encourage subordinates to share their knowledge (Bavik et al., 2018), and conversely, abusive supervision by leaders tends to reduce subordinates' engagement in KS behavior (Lee et al., 2018). However, studies that investigate the relationship between leader humor and subordinates' KS behavior have not been explored by scholars. Thus, a study that attempts to explain this relationship still needs to be done. Based on this research gap, the current study poses two main questions namely can leader humor encourage subordinates' KS behavior? If so, does the leader-member exchange (LMX) mediate such a relationship?

This study attempts to explain the relationship between leader humor and subordinates' KS behavior using the social exchange perspective. Specifically, the current study solicits to explain the effect of leader humor on subordinates' KS behavior through a leader-member exchange mechanism. Extending and investigating the relationship between leader humor and KS behavior offers several knowledge contributions in a significant and meaningful way to organizational study and management literature, especially the leadership field.

First, this study explains how and why leader humor can be a valuable predictor of KS behavior, specifically tacit knowledge. Although initial empirical evidence have revealed that leader behavior could shape and minimize subordinates' KS behavior (Bavik 
et al., 2018; Lee et al., 2018), it is still unknown empirically studies examining the relationship between leader humor and KS behavior. Thus, this study is the first attempt to consider leader humor as an essential interpersonal resource that can encourage subordinates to engage in KS behavior.

Second, this study also provides an understanding of the psychological processes underlying the relationship between leader humor and subordinates' KS behavior. Utilizing social exchange theory (SET) (Cropanzano et al., 2017; Cropanzano and Mitchell, 2005), this study identifies LMX as a mediator in such a relationship process.

Third, the current study findings may offer meaningful insight to leaders or managers in designing suitable strategies for encouraging subordinates' extraordinary behavior, such as KS behavior, based on leader humor function.

\section{THEORITICAL REVIEW}

Leader humor. Conceptually, humor was defined as "any event shared by an agent (e.g. an employee) with another individual (i.e. a target) that is intended to be amusing to the target and that the target perceives as an intentional act" (Cooper, 2005). Humor is a complex and diverse phenomenon. In the management literature, humor is seen as an intentional social communication intended to entertain (Cooper et al., 2018). Meanwhile, leader humor is the action of leaders who deliberately use humor to subordinates with a view to entertaining them (Kong et al., 2019).

Prior study has explained that leader humor can be beneficial to organizations because leaders build high-quality relationships with subordinates (Cooper et al., 2018). Humor behavior shown by leaders to subordinates can encourage positive behavior in subordinates through a high-quality exchange relationship. SET explained that members of an organization would exchange various types of resources and based on such exchange, it will produce a high-quality relationship (Cropanzano et al., 2017).

Furthermore, (Cropanzano et al., 2017) divided these types of resources into two categories: (1) economic resources; and (2) socioemotional resources. Economic resources are anything of economic value, such as formal employment contracts. In this type of resource, subordinates or employees are expected to fulfill existing obligations on the duties and responsibilities agreed upon in the contract, in return, they will be given compensation, benefits, and promotions from organizations or leaders.

Meanwhile, socioemotional resources differ from economic resources in several respects: (1) social resources are voluntary; (2) the value of socioemotional resources cannot be calculated like economic resources; (3) when socioemotional resources are given, exchanges from other parties as recipients of resources are expected but the details of the exchanges (for example, when and in what form) are usually not determined between the two parties; (4) socioemotional resources are always valued as a form of support and friendliness by the recipient.

The exchange of socioemotional resources tends to lead to high-quality relationships characterized by respect, trust, and liking, which cannot be provided by economic resources. Leader humor tends to meet criteria as a social resource because such behavior signifies the friendliness of leaders to their subordinates (Cooper et al., 2018; Kong et al., 2019). 
KS behavior. Conceptually, knowledge was defined as "certain fact, experience, information, and technology that can be earned through education, learning, mastery, and experience" (Rhee and Choi, 2017). Knowledge is an essential asset for organizations in the currently knowledge-based economy era. Organizational activities' successes and failures depend on quality knowledge they have. The available knowledge will be embedded in the routines and practices of organizations where organizations transform their knowledge into quality products and services (Davenport and Prusak, 1998; Tregua et al., 2019).

In the knowledge management field, two types of knowledge need to be managed, namely (Nonaka, 1994): (1) explicit knowledge; and (2) tacit knowledge. Explicit knowledge refers to "knowledge that is transmittable in formal, systematic language" ( $p$. 16). Meanwhile, tacit knowledge refers to knowledge that is "hard to formalize and communicate" (p. 16). This second type of knowledge is personal, intangible, and abstract. It is embedded in the experiences experienced by an individual, such as "action, commitment, and involvement in a specific context" (p. 16). Although it is challenging to formalize and communicate, tacit knowledge can still be communicated and transferred to others (Budiharjo, 2016). Thus, managing knowledge through effective KS practices become very essential in organizations' activities.

KS refers to "the provision of task information and know-how to help others and to collaborate with others to solve problems, develop new ideas, or implement policies or procedures" (Wang and Noe, 2010). Furthermore, KS behavior in an organization is seen as the basis for innovation (Laily and Ernawati, 2020) and creating new knowledge. Hence, such behavior is considered as one of the most important activities to achieve organizational effectiveness (Kim et al., 2017).

Leader humor and KS behavior. Studies explaining the relationship between leader humor and KS behavior are unknown and unexplored. This study is the first attempt to explain such a relationship process. Prior studies have explained that certain leadership behaviors and styles could encourage and reduce subordinates' KS behavior (Bavik et al., 2018; Lee et al., 2018). These results indicate that leader behaviors play an essential role in shaping subordinates' KS behavior.

Recent empirical evidence has found that leader humor could influence extraordinary behavior, such as organizational citizenship behavior (Cooper et al., 2018). It explained that one of the main functions of leader humor is to build high-quality relationships with subordinates. Thus, it could encourage subordinates' extraordinary behavior. Based on this function, this study assumes that leader humor as socioemotional resources may encourage subordinates to engage in extraordinary behavior, such as KS behavior. On the basis of the discussion above, furthermore, this study proposes the following hypothesis:

Hypothesis 1. Leader humor positively affects subordinates' KS behavior.

Leader humor and LMX. In organizations, their members develop socioemotional exchange relationships. According to the SET, both leaders and subordinates would exchange socioemotional resources with each other (Cropanzano et al., 2017). Socioemotional resource exchange is all types of exchanges that "addreses one's social and esteem needs" (Cropanzano and Mitchell, 2005). Leaders using humor as socioemotional exchange resources signals that they are supportive and friendly persons who can meet 
subordinates' social needs and self-esteem. Prior study has revealed that humor behavior from leaders could enhance high-quality LMX relationships (Cooper et al., 2018). Leadermember exchange was defined as "the perception held by subordinates as to whether or not voluntary actions on their part will be returned by the supervisor in some way" (Bernerth et al., 2007).

A series of exchanges of social resources between a leader and subordinates depends on their communication and behavioral responses, which will result in a low-quality or highquality LMX relationship (Cropanzano and Mitchell, 2005). In their task and responsibilities, because leaders are not required to behave humor to subordinates, this behavior is considered by subordinates as friendliness to them and shows that leaders try to reduce the social distance between them and their subordinates (Cooper et al., 2018; Kong et al., 2019). Hence, the more often leaders show humor behavior as a socioemotional resource to their subordinates, the more often subordinates assume that their leaders are trying to get close personally and reduce the social distance between them, which will ultimately increase the relationship of high-quality LMX. Subordinates who receive more socioemotional resources from leaders would feel motivated and obliged to maintain the quality of the relationship between them and their leaders (Abdillah et al., 2020). On the basis of the discussion above, furthermore, this study proposes the following hypothesis:

\section{Hypothesis 2. Leader humor positively causes LMX.}

LMX and KS behavior. Leaders and subordinates exchange their socioemotional resources in an organization based on the consequences of the benefits gained by both parties. The exchange process would subsequently result in a strong relationship and positive work attitudes and behavior. In high-quality socioemotional exchange relationships, mutual trust, respect, and the obligation to return or provide balanced resources tend to occur. Thus, subordinates with high-quality leader-member exchange perception would tend to perform voluntary roles beyond the formal duties that are their socioemotional obligation because they feel they are getting socioemotional resources from their leaders (Abdillah et al., 2020).

Prior study has explained that high-quality LMX relationships would tend to encourage subordinates' engagement in KS behavior (Kim et al., 2017). Using a SET perspective, Kim et al's study explained that the characteristics of leaders are essential predictors of knowledge sharing behavior. Subordinates would engage in knowledge sharing behavior when they receive positive treatment (socioemotional resources) from actors in the organization, such as leaders. In high-quality LMX relationships, subordinates who receive more socioemotional resources from their leaders would tend to try to maintain long-term relationships with their leaders. As a result, they have an obligation to take action or perform their job that exceeds their duties and responsibilities, such as engaging in KS behavior. They show such behavior as an effort to fulfill obligations because they have been treated positively by their leaders. On the basis of the discussion above, furthermore, this study proposes the following hypotheses:

Hypothesis 3. LMX positively affects subordinates' KS behavior.

Hypothesis 4. Leader humor causes LMX, which in turn affects subordinates' KH behavior. 


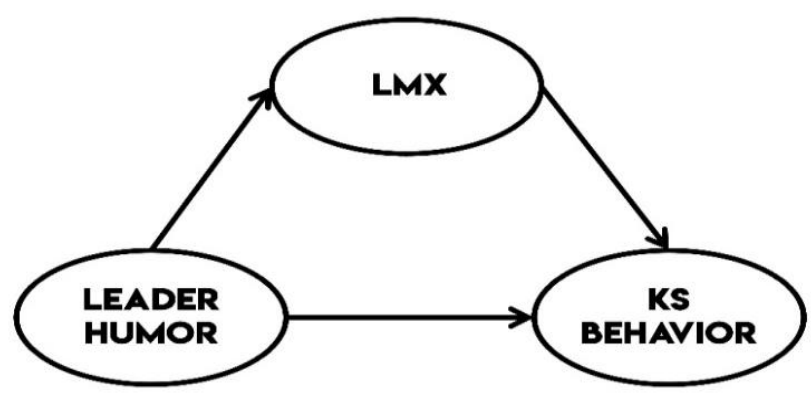

Figure 1. Theoretical framework

\section{METHODS}

Procedure and sample. This study uses primary data to test hypotheses. This study obtained data by distributing questionnaires to full-time employees who work at one of the communication and information companies in Riau Province Indonesia using a selfadministered questionnaire. This company was chosen because previous studies have recognized this type of organization as usually doing the knowledge exchange process in its daily activity (Abdillah et al., 2020; Rhee and Choi, 2017). Questionnaires were distributed by the convenience sampling method. 55 employees were invited to be involved in filling out the questionnaire. However, from all questionnaires distributed, only 39 employees volunteered to be involved in filling out the questionnaire.

Due to all items used to measure all variables in this study were adopted from journal articles written in English, all questionnaire items would be translated into Indonesian using the "translation-back procedure" technique. This technique translated all items from the original language into Indonesian, and then it is translated back to its original language to ensure the translation results do not reduce the content of all questionnaire items (Colina et al., 2017).

Measurement. The measurement of each variable is needed to link abstract concepts (variables) with empirical observations. The variables in this study consisted of: (1) the independent variable, namely leader humor; (2) mediating variables, namely LMX; and (3) the dependent variable, namely KS behavior.

Leader humor in the current study was measured through four items adopted from (Cooper et al., 2018) and (Yam et al., 2018). Respondents were asked to provide their perceptions about their leader behavior including "my leader expresses humor with me at work," "my leader injected humor into many types of situations when interacting with me," "my leader jokes around with me," and "my leader uses humor to entertain coworkers." They answered all items on a "seven-point scale" ranging from 1 ("never") to 7 ("always").

$L M X$ in the current study was measured through eight items adopted from Bernerth et al. (2007). Subordinates were asked to provide their perceptions about the quality LMX at their workplace including "my leader and I have a two-way exchange relationship," "I do not have to specify the exact conditions to know my leader will return a favor," "If I do something for my immediate leader, he/she will eventually payback to me," "I have a balance of inputs and outputs with my leader," "my efforts are reciprocated by my leader," "my relationship with my leader is composed of comparable exchanges of giving and 
taking," "when I give effort at work, my leader will return it," and "voluntary actions on my part will be returned in some way by my leader." Respondents answered all items on a "seven-point scale" ranging from 1 ("strongly disagree") to 7 ("strongly agree").

KH behavior in the current study was measured through four items adopted from (Staples and Webster, 2008). Respondents were asked to remember their current interaction with their colleagues and answer the questions including "I am willing to share knowledge/ideas with others," "I share my ideas with my co-worker," "I am willing to share my experiences or know-how to help others in my organization," and "I keep my best ideas to myself (reverse code)." They answered all items on a "seven-point scale" ranging from 1 ("strongly disagree") to 7 ("strongly agree").

Data analysis. The hypothesis in this study was tested using PLS-SEM analysis through WarpPLS 5.0 software (Latan et al., 2019; Weerawardena et al., 2015). There are several reasons why the current study used SEM-PLS analysis in analyzing data. First, PLS-SEM analysis technique is capable of simultaneously estimating structural models and measurement models. Second, SEM-PLS is a very powerful tool when used to test a newly developed model. Third, this analysis technique is suitable for a study that has a small sample size.

Data analysis in this study consisted of several stages. First, this study conducts a "fit model and quality indices" test, that aims to determine whether the model built in this study is good or not (Wetzels et al., 2009). Second, this study analyzes the measurement model by testing the validity of the measurement scale for each variable (Chin, 2010). Validity tests on the measurement scale of each variable are discriminant validity, convergent validity, and reliability tests (Hair et al., 2014). Third, this study considers testing the "common method variance" which aims to see whether the data in this study produces a "common method bias" problem or not (Podsakoff et al., 2003; 2012). Finally, the current study carries out a structural model analysis that aims to test all the hypotheses that have been proposed.

\section{RESULTS}

Fit model and quality indices. The results of the PLS-SEM analysis in assessing the model fit and quality indices in this study comprise average R-squared (ARS), average path coefficient (APC), and average block VIF (AVIF). The results in table 1 reveal that the model built in this study is compatible with empirical data [ARS $=0.506(p<0.001) ; \mathrm{APC}=$ $0.567(p<0.001)$; AVIF $=2.169]$. AVIF value lower than 3.3 indicates that the model in this study does not produce multicollinearity problems (Hair et al., 2014). 
Table 1. Model fit and quality indices

\begin{tabular}{|c|c|c|}
\hline Quality indices criteria & Value & Rule of thumb \\
\hline Average path coefficient (APC) & $0.506^{* * *}$ & $p$-value $<0,05$ \\
\hline Average R-squared (ARS) & $0.567^{* * *}$ & $p$-value $<0,05$ \\
\hline Average block VIF (AVIF) & 2.169 & $<3,3$ \\
\hline Tenenhaus GoF (GoF) & 0.680 & $\begin{array}{l}\geq 0,10(\text { small effect size }), \geq 0,25 \text { (medium effect size }), \\
\text { dan } \geq 0,36(\text { large effect size })\end{array}$ \\
\hline $\begin{array}{l}\text { Q-squared }\left(\mathrm{Q}^{2}\right) \text { coefficient: } \\
\text { - } \mathrm{LMX} \\
\text { - } \mathrm{KS} \text { behavior }\end{array}$ & $\begin{array}{l}0.531 \\
0.594\end{array}$ & $>0$ (acceptabel predictive model) \\
\hline
\end{tabular}

Furthermore, table 1 also reveals the value of the Tenenhaus GoF (GoF) which aims to evaluate the suitability of the outer model and inner model in PLS (Tenenhaus et al., 2005). The cut-off values for GoF are 0.1 (small), 0.25 (medium), and 0.36 (large) (Wetzels et al., 2009). The results in the table reveal that the GoF value is 0.680 , which is greater than the threshold value of 0.36 . These results indicate that the model in this study has a large effect size. In addition, the $\mathrm{Q}^{2}$ coefficients in the table also show the values greater than zero, which explain that the model has an acceptable predictive value (O'Cass and Weerawardena, 2010).

Measurement model analysis. Analysis of the measurement model in PLS-SEM aims to evaluate the construct validity of each variable. This analysis, especially on constructs measured using reflective items, consists of three steps (Hair et al., 2014). First, this analysis tests the reliability of each variable. It is performed by evaluating Cronbach's alpha $(\alpha)$ and composite reliability (C.R.) values. The values of $\alpha$ and C.R. of each variable must be above 0.80 .

Second, this analysis also tests convergent validity, which is done by evaluating loadings, and average variance extracted (AVE). The loadings value must range from 0.70 to 0.90. Furthermore, the AVE value above the cut-off value of 0.50 for all constructs is required (Chin, 2010). Third, this analysis further tests discriminant validity using the (Fornell and Larcker, 1981) criterion, where the correlation between constructs (variables) must be below the square root of AVE. The finding in this study (tables 2 and 3) indicates that the results of validity testing meet each construct validity requirement.

Table 2. Correlations among variables and discriminant validity test

\begin{tabular}{lllc}
\hline & Leader humor & LMX & KS behavior \\
\hline Leader humor & $\mathbf{0 . 9 5 7}$ & & \\
LMX & $0.734^{* * *}$ & $\mathbf{0 . 9 1 8}$ & \\
KS behavior & $0.588^{* * *}$ & $0.771^{* * *}$ & $\mathbf{0 . 8 3 0}$ \\
${ }^{* * *}=p<0.001 ;$ The diagonal column shows the square root of average variances extracted (AVEs)
\end{tabular}


Table 3. Reliability and convergent validity tests

\begin{tabular}{lllllr}
\hline \multicolumn{1}{c}{ Variables } & \multicolumn{1}{c}{ Items } & Loadings & AVE & C.R. & $\boldsymbol{\alpha}$ \\
\hline Leader humor & LH01 & 0.959 & 0.916 & 0.978 & 0.969 \\
& LH02 & 0.962 & & & \\
& LH03 & 0.946 & & & \\
LMX & LH04 & 0.962 & & & \\
& LMX01 & 0.933 & 0.842 & 0.977 & 0.973 \\
& LMX02 & 0.930 & & & \\
& LMX03 & 0.908 & & & \\
& LMX04 & 0.946 & & & \\
KS behavior & LMX05 & 0.913 & & & \\
& LMX06 & 0.935 & & & \\
& LMX07 & 0.870 & & & \\
& LMX08 & 0.903 & & & \\
& KSB01 & 0.872 & 0.688 & 0.895 & \\
& KSB03 & 0.913 & & & \\
& KSB04 & 0.940 & & & \\
\hline
\end{tabular}

Common method variance (CMV) test. This current study is a cross-sectional, namely collecting data in "a single point in time," and getting data from the same source. Thus, it is possible that the data might still have the potential to produce a "common method bias" (Podsakoff et al., 2003; 2012). To ensure that the common method variance can be controlled, this study evaluates the value of the block variance inflation factor (Kock, 2015). Table 4 shows that the value of the block variance inflation factor is lower than 3.3. Hence, it can be concluded that the data in this study do not have the potential to produce a "common method bias" (Kock, 2015)

Table 4. Block variance inflation factor

\begin{tabular}{lll}
\hline & Leader humor & LMX \\
\hline Leader humor & 2.169 & 2.169 \\
\hline
\end{tabular}

Structural model analysis. As explained above, structural model analysis functions to test study hypotheses. Table 5 shows the path coefficients generated by structural model analysis on PLS-SEM. In model 1, without using mediating variables, leader humor positively affects subordinates' KS behavior $(\beta=0.588, p<0.001)$. This finding statistically supports hypothesis 1 . Furthermore, in table 5 , especially in model 2 , it shows that leader humor positively affects $\operatorname{LMX}(\beta=0.734, p<0.001)$. This result statistically supports hypothesis 2 which states that leader humor causes LMX. In the table, it can also be seen that LMX positively affects subordinates' $\mathrm{KS}$ behavior $(\beta=0.735, p<0.001)$. This finding statistically supports hypothesis 3 .

In addition, table 5 also reveals that LMX mediates the effect of the leader humor on KS behavior $(\beta=0.539, p<0.001)$. This finding statistically supports hypothesis 4 which states that Leader humor causes LMX, which in turn affects subordinates' KH behavior. In the table, it can also be seen that when LMX variable is entered into model 2, the influence of the leader humor on subordinates' KS behavior becomes insignificant $(\beta=0.049$, n.s. $)$. 
This finding describes that LMX fully mediates the relationship between leader humor and subordinates' KS behavior.

Table 5. Hypotheses testing

\begin{tabular}{lc}
\hline Model 1: Without mediation variable & \\
Direct effect & \\
Leader humor $\rightarrow$ KS behavior & $0.588^{* * *}$ \\
$\mathrm{R}^{2}($ KS behavior) & 0.346 \\
\hline Model 2: Full model & \\
Direct effect & \\
Leader humor $\rightarrow$ KS behavior & $0.049^{t . s .}$ \\
Leader humor $\rightarrow$ LMX & $0.734^{* * * *}$ \\
LMX $\rightarrow$ KS behavior & $0.735^{* * *}$ \\
\hline Indirect effect & \\
Leader humor $\rightarrow$ KS behavior & $0.539^{* * *}$ \\
\hline Total effect & \\
Leader humor $\rightarrow$ KS behavior & $0.588^{* * * *}$ \\
\hline $\boldsymbol{R}$-squared & \\
$\mathrm{R}^{2}$ (LMX) & 0.539 \\
$\mathrm{R}^{2}$ KS behavior) & 0.595 \\
$n=$ not significant; ${ }^{* * *}=p<0.001$. &
\end{tabular}

\section{DISCUSSION}

Leader humor is a social communication intending to give amusement from leaders to their subordinates. This behavior is very useful to encourage high-quality interaction between employees and leaders in organizations. This study is the first attempt in trying to explain the relationship between leader humor and subordinates' KS behavior. By utilizing SET perspective in organizations (Cropanzano et al., 2017; Cropanzano and Mitchell, 2005), this study attempts to explain how and why leader humor may encourage KS behavior among subordinates. Using a sample of full-time employees at communication and information company in Pekanbaru City, Riau, Indonesia, the finding revealed that humor behavior used by leaders or managers positively affects the quality of the relationship between leaders and subordinates and subordinates' KS behavior. The theoretical and practical implications of the study finding would be explained next.

Theoretical implications. The primary contribution of the current study lies in the relationship between leader humor and KS behavior among subordinates. Recent empirical evidence shows that leadership styles or leader behaviors could encourage and reduce knowledge sharing behavior among subordinates (Bavik et al., 2018; Lee et al., 2018). These results provide initial evidence that leader behavior plays an essential role in encouraging subordinates' KS behavior. The finding of the current study revealed that leader humor positively affects KS behavior (hypothesis 1). This result indicates that humor behavior from leaders can encourage KS behavior among subordinates. This result extends empirical evidence and understanding that leaders and their behaviors play a critical role in encouraging subordinates' KS behavior. This finding also advances current knowledge that humor behavior used by leaders to amuse their subordinates can encourage subordinates to share their knowledge through high-quality relationships between leaders and subordinates. 
Furthermore, the current study also revealed that leader humor positively affects LMX (hypothesis 2), and LMX positively affects KS behavior (hypothesis 3). These results indicate that humor behavior from leaders can establish high-quality relationships between leaders and subordinates through LMX, which in turn can encourage subordinates' KS behavior. By utilizing SET perspective in organizations (Cropanzano et al., 2017; Cropanzano and Mitchell, 2005), the findings of this study which found that LMX quality mediates the relationship between leader humor and KS behavior among subordinates (hypothesis 4), has a contribution on further understanding of the psychological mechanism from the function of LMX in the relationship between leader humor and subordinates' extraordinary behavior (Cooper et al., 2018; Kong et al., 2019). The current study advances the understanding of how and why humor behavior by leaders can improve high-quality interaction between leaders and subordinates, which in turn can encourage subordinates to engage in KS behavior.

Humor behavior considered by subordinates as friendliness to them raises the perception of subordinates that leaders with humility try to reduce the social distance between leaders and subordinates. The positive treatment received by subordinates from organizational actors such as leaders will establish high-quality interaction relationships between leaders and subordinates. In high-quality relationships between subordinates and leaders, subordinates will tend to attempt to maintain a long-term relationship with their leaders. Thus, they feel had an obligation for carrying out extraordinary actions or behaviors that exceed their duties and responsibilities, such as engaging in KS behavior. They perform such behavior as an effort to fulfill obligations because they have been treated friendly by their leaders.

Managerial implications. In addition to having theoretical implications, this study also provides a critical insight for managers about how organizations can encourage their employees to engage in KS behavior. Using humor by leaders is a social resource that can be utilized by managers in order to improve the effectiveness of managing people in organizations. Humor behavior used by leaders can be an essential instrument, especially for managers who have limited access to economic resources. This behavior can establish a high-quality relationship between managers and their subordinates, which will ultimately motivate subordinates to take action or performance that exceeds their duties and responsibilities.

This study recommends that the use of humor by managers is an effective and efficient way in the process of influencing subordinates to achieve organizational goals because this behavior can enrich the leadership process. Manager can use humor at the workplace. He or she can try to express humor with subordinates. He or she also can inject humor into many conditions when he or she interacts with his or her subordinates. A leader can use jokes around with his or her subordinates. He or she can also use this behavior to entertain his or her subordinates.

Limitation and future studies. Each study always has limitations. Likewise, the current study has several limitations that must be conveyed. First, this study was limited to samples taken from a company engaged in the field of communication and information at a city in Indonesia so that it has limitations in generalizing to other types of companies or industries. Hence, for future studies, it is needed testing on companies engaged in other industries such 
as hospitality, manufacturing, and financial and banking institutions. Second, this study is a cross-sectional study that collected data in "a single point in time," and got data from the same source, namely employees. Although the statistical finding showed that the data in this study are free from the problem of "common method bias" (Podsakoff et al., 2003; 2012), for further studies, it is recommended using a multiple-time and source data in designing a study. Third, this study only chose leader humor as a mechanism in encouraging or influencing employees to perform extraordinary behavior. Hence, for further studies, it is expected to investigate other mechanisms such as humble leadership (Ali et al., 2020; Yang et al., 2019) which may also be useful as a driving factor of subordinates' extraordinary behavior such as KS behavior, organizational citizenship behavior or behavior innovative employee.

\section{CONCLUSION}

The current study makes valuable contributions to the management literature, especially in fields of leadership, organizational behavior, and knowledge management. By utilizing SET perspective, the findings in this study extend understanding of how and why the humor behavior by leaders can encourage subordinates to share their knowledge. The findings in the current study also provide a new way for organizations, especially managers, in designing appropriate strategies to encourage or influence subordinates to engage in extraordinary behaviors such as KS behavior. This study also extends the understanding of academics and practitioners about the empirical evidence supporting leader humor as a socioemotional resource that can improve high-quality interaction between leaders and subordinates in organizations. Finally, the current study also expects that this study findings in the future can be a catalyst for academics to pay more attention to the relationship between leader behavior and subordinates' extraordinary behavior and its process mechanism.

\section{REFERENCES}

Abdillah, M. R., Wu, W., and Anita, R. (2020). Can altruistic leadership prevent knowledgehiding behaviour? Testing dual mediation mechanisms. Knowledge Management Research and Practice. https://doi.org/10.1080/14778238.2020.1776171.

Ali, M., Zhang, L., Shah, S. J., Khan, S., and Shah, A. M. (2020). Impact of humble leadership on project success: the mediating role of psychological empowerment and innovative work behavior. Leadership and Organization Development Journal, 41(3), 349-367. https://doi.org/10.1108/LODJ-05-2019-0230.

Barley, W. C., Treem, J. W., and Kuhn, T. (2018). Valuing multiple trajectories of knowledge: A critical review and agenda for knowledge management research. Academy of Management Annals, 12(1), 278-317. https://doi.org/10.5465/annals.2016.0041.

Bavik, Y. L., Tang, P. M., Shao, R., and Lam, L. W. (2018). Ethical leadership and employee knowledge sharing: Exploring dual-mediation paths. Leadership Quarterly, 29(2), 322-332. https://doi.org/10.1016/j.leaqua.2017.05.006.

Bernerth, J. B., Armenakis, A. A., Feild, H. S., Giles, W. F., and Walker, H. J. (2007). Leader-member social exchange (LMSX): Development and validation of a scale. Journal of Organizational Behavior, 28(8), 979-1003. 
https://doi.org/10.1002/job.443.

Budiharjo, A. (2016). Knowledge management: Efektif berinovasi meraih sukses. Prasetiya Mulya Publishing.

Carmeli, A., Gelbard, R., and Reiter-Palmon, R. (2013). Leadership, Creative ProblemSolving Capacity, and Creative Performance: The Importance of Knowledge Sharing. Human Resource Management, 52(1), 95-121. https://doi.org/10.1002/hrm.21514.

Chin, W. W. (2010). How to Write Up and Report PLS Analyses. In Handbook of Partial Least Squares (pp. 655-690). Springer Berlin Heidelberg. https://doi.org/10.1007/978-3-540-32827-8_29.

Colina, S., Marrone, N., Ingram, M., and Sánchez, D. (2017). Translation Quality Assessment in Health Research: A Functionalist Alternative to Back-Translation. Evaluation \& the Health Professions, 40(3), 267-293. https://doi.org/10.1177/0163278716648191.

Connelly, C. E., Černe, M., Dysvik, A., and Škerlavaj, M. (2019). Understanding knowledge hiding in organizations. Journal of Organizational Behavior, 40(7), 779-782. https://doi.org/10.1002/job.2407.

Connelly, C. E., Zweig, D., Webster, J., and Trougakos, J. P. (2012). Knowledge hiding in organizations. Journal of Organizational Behavior, 33(1), 64-88. https://doi.org/10.1002/job.737.

Cooper, C. D. (2005). Just joking around? employee humor expression as an ingratiatory behavior. In Academy of Management Review (Vol. 30, Issue 4, pp. 765-776). Academy of Management. https://doi.org/10.5465/AMR.2005.18378877.

Cooper, C. D., Kong, D. T., and Crossley, C. D. (2018). Leader humor as an interpersonal resource: Integrating three theoretical perspectives. Academy of Management Journal, 61(2), 769-796. https://doi.org/10.5465/amj.2014.0358.

Cooper, C. D., and Sosik, J. J. (2012). The laughter advantage: Cultivating high quality connections and workplace outcomes through humor. In The handbook of positive organizational scholarship (pp. 474-489). Oxford University Press. https://doi.org/10.1093/OXFORDHB/9780199734610.013.0036.

Cropanzano, R., Anthony, E. L., Daniels, S. R., and Hall, A. V. (2017). Social exchange theory: A critical review with theoretical remedies. In Academy of Management Annals (Vol. 11, Issue 1, pp. 479-516). Routledge. https://doi.org/10.5465/annals.2015.0099.

Cropanzano, R., and Mitchell, M. S. (2005). Social Exchange Theory: An Interdisciplinary Review. Journal of Management, 31(6), 874-900. https://doi.org/10.1177/0149206305279602.

Curado, C., Oliveira, M., Maçada, A. C. G., and Nodari, F. (2017). Teams' innovation: getting there through knowledge sharing and absorptive capacity. Knowledge Management Research \& Practice, 15(1), 45-53. https://doi.org/10.1057/kmrp.2015.8.

Davenport, T. H., and Prusak, L. (1998). Working Knowledge: How Organizations Manage what Khey Know. Harvard Business Press. https://books.google.co.id/books/about/Working_Knowledge.html?id=-47vmCVG5cC\&redir_esc $=y$.

Fornell, C., and Larcker, D. F. (1981). Evaluating Structural Equation Models with Unobservable Variables and Measurement Error. Journal of Marketing Research, 
18(1), 39-50. https://doi.org/10.1177/002224378101800104.

Hair, J. F., Sarstedt, M., Hopkins, L., and Kuppelwieser, V. G. (2014). Partial least squares structural equation modeling (PLS-SEM): An emerging tool in business research. In European Business Review (Vol. 26, Issue 2, pp. 106-121). Emerald Group Publishing Ltd. https://doi.org/10.1108/EBR-10-2013-0128.

Inceoglu, I., Thomas, G., Chu, C., Plans, D., and Gerbasi, A. (2018). Leadership behavior and employee well-being: An integrated review and a future research agenda. Leadership Quarterly, 29(1), 179-202. https://doi.org/10.1016/j.leaqua.2017.12.006.

Ismail, N. A. M., Welch, C., and Xu, M. (2015). Towards a sustainable quality of university research: Knowledge sharing. Knowledge Management Research and Practice, 13(2), 168-177. https://doi.org/10.1057/kmrp.2013.39.

Kakar, A. K. (2018). How do team conflicts impact knowledge sharing? Knowledge Management Research and Practice, 16(1), 21-31. https://doi.org/10.1080/14778238.2017.1401194.

Kim, S. L., Han, S., Son, S. Y., and Yun, S. (2017). Exchange ideology in supervisorsubordinate dyads, LMX, and knowledge sharing: A social exchange perspective. Asia Pacific Journal of Management, 34(1), 147-172. https://doi.org/10.1007/s10490-016-9483-y.

Kock, N. (2015). Common method bias in PLS-SEM: A full collinearity assessment approach. International Journal of E-Collaboration, 11(4), 1-10. https://doi.org/10.4018/ijec.2015100101.

Kong, D. T., Cooper, C. D., and Sosik, J. J. (2019). The state of research on leader humor. Organizational Psychology Review, 9(1), 3-40. https://doi.org/10.1177/2041386619846948.

Laily, N., and Ernawati, D. P. (2020). The Effect of Knowledge Sharing and Innovation Behavior on The Performance of Batik Entrepreneurs. Jurnal Manajemen, 24(2), 194-209. http://dx.doi.org/10.24912/jm.v24i1.643.

Latan, H., Chiappetta Jabbour, C. J., and Lopes de Sousa Jabbour, A. B. (2019). 'Whistleblowing Triangle': Framework and Empirical Evidence. Journal of Business Ethics, 160(1), 189-204. https://doi.org/10.1007/s10551-018-3862-x.

Lee, S., Kim, S. L., and Yun, S. (2018). A moderated mediation model of the relationship between abusive supervision and knowledge sharing. Leadership Quarterly, 29(3), 403-413. https://doi.org/10.1016/j.leaqua.2017.09.001.

Li, J., Yuan, L., Ning, L., and Li-Ying, J. (2015). Knowledge sharing and affective commitment: the mediating role of psychological ownership. Journal of Knowledge Management, 19(6), 1146-1166. https://doi.org/10.1108/JKM-01-2015-0043.

Nonaka, I. (1994). A Dynamic Theory of Organizational Knowledge Creation. Organization Science, 5(14-37). https://doi.org/https://doi.org/10.1287/orsc.5.1.14.

O'Cass, A., and Weerawardena, J. (2010). The effects of perceived industry competitive intensity and marketing-related capabilities: Drivers of superior brand performance. Industrial Marketing Management, 39(4), 571-581. https://doi.org/10.1016/j.indmarman.2009.04.002.

Pangil, F., and Chan, J. M. (2014). The mediating effect of knowledge sharing on the relationship between trust and virtual team effectiveness. Journal of Knowledge Management, 18(1), 92-106. https://doi.org/10.1108/JKM-09-2013-0341.

Podsakoff, P. M., MacKenzie, S. B., Lee, J. Y., and Podsakoff, N. P. (2003). Common 
Method Biases in Behavioral Research: A Critical Review of the Literature and Recommended Remedies. In Journal of Applied Psychology (Vol. 88, Issue 5, pp. 879-903). https://doi.org/10.1037/0021-9010.88.5.879.

Podsakoff, P. M., MacKenzie, S. B., and Podsakoff, N. P. (2012). Sources of Method Bias in Social Science Research and Recommendations on How to Control It. Annual Review of Psychology, 63(1), 539-569. https://doi.org/10.1146/annurev-psych120710-100452.

Rhee, Y. W., and Choi, J. N. (2017). Knowledge management behavior and individual creativity: Goal orientations as antecedents and in-group social status as moderating contingency. Journal of Organizational Behavior, 38(6), 813-832. https://doi.org/10.1002/job.2168.

Rosendaal, B., and Bijlsma-Frankema, K. (2015). Knowledge sharing within teams: Enabling and constraining factors. Knowledge Management Research and Practice, 13(3), 235-247. https://doi.org/10.1057/kmrp.2013.45.

Staples, D. S., and Webster, J. (2008). Exploring the effects of trust, task interdependence and virtualness on knowledge sharing in teams. Information Systems Journal, 18(6), 617-640. https://doi.org/10.1111/j.1365-2575.2007.00244.x.

Sudhindra, S., Ganesh, L. S., and Kaur, A. (2019). Strategic parameters of knowledge sharing in supply chains. Knowledge Management Research and Practice. https://doi.org/10.1080/14778238.2019.1654417.

Tenenhaus, M., Vinzi, V. E., Chatelin, Y. M., and Lauro, C. (2005). PLS path modeling. Computational Statistics and Data Analysis, 48(1), 159-205. https://doi.org/10.1016/j.csda.2004.03.005.

Tregua, M., D'Auria, A., and Brozovic, D. (2019). Value-oriented knowledge management: insights from theory and practice. Knowledge Management Research and Practice, 1-11. https://doi.org/10.1080/14778238.2020.1789003.

Vlachos, I., Siachou, E., and Langwallner, E. (2020). A perspective on knowledge sharing and lean management: an empirical investigation. Knowledge Management Research and Practice, 18(2), 131-146. https://doi.org/10.1080/14778238.2019.1589399.

Wang, S., and Noe, R. A. (2010). Knowledge sharing: A review and directions for future research. Human Resource Management Review, 20(2), 115-131. https://doi.org/10.1016/j.hrmr.2009.10.001.

Weerawardena, J., Mort, G. S., Salunke, S., Knight, G., and Liesch, P. W. (2015). The role of the market sub-system and the socio-technical sub-system in innovation and firm performance: a dynamic capabilities approach. Journal of the Academy of Marketing Science, 43(2), 221-239. https://doi.org/10.1007/s11747-014-0382-9.

Wetzels, M. G. M., Odekerken-Schröder, G., and Oppen, C. van. (2009). Using PLS path modeling for assessing hierarchical construct models: guidelines and empirical illustration. MIS Quarterly, 33(1), 177-195.

Wipawayangkool, K., and Teng, J. T. C. (2019). Profiling knowledge workers' knowledge sharing behavior via knowledge internalization. Knowledge Management Research and Practice, 17(1), 70-82. https://doi.org/10.1080/14778238.2018.1557798.

Yam, K. C., Christian, M. S., Wei, W., Liao, Z., and Nai, J. (2018). The mixed blessing of leader sense of humor: Examining costs and benefits. Academy of Management Journal, 61(1), 348-369. https://doi.org/10.5465/amj.2015.1088.

Yang, K., Zhou, L., Wang, Z., Lin, C., and Luo, Z. (2019). Humble leadership and 
innovative behaviour among Chinese nurses: The mediating role of work engagement. Journal of Nursing Management, 27(8), 1801-1808. https://doi.org/10.1111/jonm.12879.

Yen, Y. F., Tseng, J. F., and Wang, H. K. (2015). The effect of internal social capital on knowledge sharing. Knowledge Management Research and Practice, 13(2), 214-224. https://doi.org/10.1057/kmrp.2013.43.

Yeo, R. K., and Marquardt, M. J. (2015). To share or not to share? Self-perception and knowledge-sharing intent. Knowledge Management Research and Practice, 13(3), 311-328. https://doi.org/10.1057/kmrp.2013.52. 